Article

\title{
Therapy of Subclinical Mastitis during Lactation
}

\author{
Scott McDougall ${ }^{1,2, *(D)}$, Laura M. Clausen ${ }^{1}$, Hassan M. Hussein ${ }^{1}$ and Chris W. R. Compton ${ }^{2}$ \\ 1 Cognosco, Anexa Veterinary Services, Morrinsville 3340, New Zealand; lmclausen@gmail.com (L.M.C.); \\ h-hussein@xtra.co.nz (H.M.H.) \\ 2 School of Veterinary Science, Massey University, Palmerston North 4442, New Zealand; \\ C.W.Compton@massey.ac.nz \\ * Correspondence: smcdougall@anexa.co.nz; Tel.: +64-021-800-341
}

Citation: McDougall, S.; Clausen,

L.M.; Hussein, H.M.; Compton,

C.W.R. Therapy of Subclinical

Mastitis during Lactation. Antibiotics 2022, 11, 209. https://doi.org/ 10.3390 /antibiotics11020209

Academic Editor: Volker Krömker

Received: 8 December 2021

Accepted: 3 February 2022

Published: 7 February 2022

Publisher's Note: MDPI stays neutral with regard to jurisdictional claims in published maps and institutional affiliations.

Copyright: (C) 2022 by the authors. Licensee MDPI, Basel, Switzerland. This article is an open access article distributed under the terms and conditions of the Creative Commons Attribution (CC BY) license (https:// creativecommons.org/licenses/by/ $4.0 /)$.

\begin{abstract}
This study tested the hypothesis that increasing the duration and/or frequency of antimicrobial treatment of subclinical mastitis would result in a higher bacteriological cure rate. Glands with a positive California mastitis test (CMT) from cows with an elevated somatic cell count $(>500,000$ cells $/ \mathrm{mL}$ ) that had an intramammary infection were randomly assigned at cow level to no treatment (Control; $n=80$ glands), intramammary infusion of $200 \mathrm{mg}$ cloxacillin sodium on three occasions at $48 \mathrm{~h}$ intervals $(3 \times 48 \mathrm{~h} ; n=273$ glands), five occasions at $24 \mathrm{~h}$ intervals $(5 \times 24 \mathrm{~h}$; $n=279$ glands), or on five occasions at $48 \mathrm{~h}$ intervals $(5 \times 48 \mathrm{~h} ; n=72$ glands). Glands were resampled at $21( \pm 3)$ and $28( \pm 3)$ days after initiation of treatment. The gland-level cure rate for any pathogen was 5/80 (6.2\%), 139/173 (49.8\%), 172/297 (61.6\%) and 58/72 (80.6\%) for Control, $3 \times 48$ h, $5 \times 24 \mathrm{~h}$ and $5 \times 48 \mathrm{~h}$, respectively. The cure rate for major pathogens (defined as Staphylococcus aureus or Streptococcus spp.) was 4/52 (7.7\%), 84/197 (42.6\%), 96/183 (52.5\%) and 36/48 (75\%) for Control, $3 \times 48$ h, $5 \times 24$ h and $5 \times 48$ h, respectively. We conclude that treatment was superior to no treatment, and bacteriological cure rate was higher with the $5 \times 24 \mathrm{~h}$ protocol than for the $3 \times 48 \mathrm{~h}$ protocol and was higher with the $5 \times 48 \mathrm{~h}$ than the $5 \times 24$ h protocol.
\end{abstract}

Keywords: mastitis; subclinical; therapy; cloxacillin; duration; frequency; Staphylococcus aureus; Streptococcus uberis

\section{Introduction}

Mastitis results in a range of clinical signs, from subclinical mastitis through to grossly evident local or systemic disease [1]. While clinical mastitis is commonly treated with antimicrobials and nonsteroidal anti-inflammatory drugs, subclinical cases are not commonly treated. However, there is production loss associated with subclinical infection [2], and these infections may act as a source of infection for other animals in the herd. Treatment of subclinical cases increases bacteriological cure rates [3,4], reduces SCC [3,5], reduces incidence of clinical mastitis [3,4] and potentially reduces forward transmission [6] compared with leaving quarters untreated.

Bacteriological curing of mastitis following antimicrobial therapy is affected by cow age [7], gland position (front vs. rear gland), the number of glands within a cow involved, the previous SCC, dry cow therapy treatment history [7-9], the pathogen [7,10], antimicrobial resistance $[5,11,12]$ and presence of gland/teat end damage.

For time-dependent antimicrobials such as beta-lactams, macrolides, and lincosamides, maintaining concentrations of the antimicrobial above MIC between $40-100 \%$ of the dosing interval and for a longer period are associated with higher bacteriological cure rates $[13,14]$. Bacteriological cure rates of subclinical intramammary infections were $10.5 \%, 38.8 \%, 53.7 \%$, and $75.8 \%$, respectively, following $0,2,5$, or 8 days of intramammary treatment with $125 \mathrm{mg}$ /day of ceftiofur [15]. Similarly, bacteriological cure rates of Staph. aureus of 6\%, $56 \%$ and $86 \%$ were achieved following zero, two or eight intramammary treatments with $50 \mathrm{mg} /$ day of pirlimycin, respectively [4], and cure rates of naturally acquired Staph. aureus 
or Streptococcus species infection were $0 \%, 44 \%, 61 \%$, and $95 \%$ following treatment with nothing, or two, five, or eight daily intramammary doses of $50 \mathrm{mg}$ of pirlimycin, respectively [16]. Similarly, the bacteriological cure rates were $16 \%, 32 \%$, and 56\% with no treatment, or following parenteral treatment with penethamate on three or six occasions at $24 \mathrm{~h}$ intervals, respectively, in subclinical glands [5]. However, a more recent study found no difference in bacterial cure rate between clinical mastitis cases assigned to three intramammary infusions at 12-hourly intervals compared with five infusions at 12-hourly intervals with amoxicillin clavulanic acid [17]. Similarly, similar bacteriological cure rates and similar survival rates were found following $3 \times 12$ hourly amoxicillin, $5 \times 24$ hourly amoxicillin or $5 \times 24$ hourly ceftiofur intramammary treatments of Gram-positive clinical mastitis cases [18].

Penicillin-resistant Staph. aureus is common amongst bovine mastitis isolates [19-21]. Resistance is conferred by beta-lactamases which are produced by the blaZ gene, which is commonly located on plasmids, but may also be located on chromosomes [22]. Cloxacillin is an anti-staphylococcal isoxazoyl penicillin that is beta-lactamase (pencillinase)-stable and hence may be effective against Staph. aureus strains producing this enzyme [23]. Cloxacillin has been extensively used as an intramammary therapy for mastitis, both during lactation $[24,25]$ and at the end of lactation as dry cow therapy $[26,27]$.

The primary objective of this study was to evaluate the bacteriological cure proportion and change in gland-level SCC following two durations and two frequencies of therapy with intramammary cloxacillin for treatment of naturally acquired subclinical mastitis cases on commercial dairy farms. It was hypothesized that treatment of subclinical mastitis with cloxacillin would result in a superior bacteriological cure rate than no treatment, and that increasing duration and/or frequency of treatment would result in higher bacteriological cure rates.

\section{Results}

\subsection{Pretreatment Bacteriology}

In total, 33\% of all CMT-positive glands sampled were bacteriological-negative. Of the bacteriological-positive glands, the most prevalent pathogen isolated was Staph. aureus ( $n=270,37.7 \%$ ), followed by Corynebacterium spp. and Strep. uberis (Table 1). A further 68 Staph. aureus isolates were recovered from mixed intramammary infections (IMI) from pretreatment samples. When gland results were grouped by pathogen types (major = Staph. aureus, Strep. uberis, Strep. dysgalactiae, Strep. agalactiae, E. coli, Nocardia spp.; minor = non-aureus staphylococci, Corynebacterium spp., Gram-negative rods) there was no difference in their distribution among treatment groups $(p=0.32)$. 
Table 1. Distribution (number of glands (No.)) of bacteriology results before treatment, and bacteriological cure rate (\%) by treatment group among bacteriological-positive glands treated with intramammary cloxacillin on 3 occasions at $48 \mathrm{~h}$ intervals $(3 \times 48 \mathrm{~h}), 5$ times at $24 \mathrm{~h}$ intervals $(5 \times 24 \mathrm{~h})$, or 5 times at $48 \mathrm{~h}$ intervals $(5 \times 48 \mathrm{~h})$ or left as untreated controls following diagnosis with subclinical mastitis. The total number of glands and total number of cows are the number of glands and cows included in the final analyses.

\begin{tabular}{|c|c|c|c|c|c|c|c|c|c|c|c|}
\hline & & \multicolumn{2}{|c|}{ Control } & \multicolumn{2}{|c|}{$3 \times 48 \mathrm{~h}$} & \multicolumn{2}{|c|}{$5 \times 24 \mathrm{~h}$} & \multicolumn{2}{|c|}{$5 \times 48 \mathrm{~h}$} & \multicolumn{2}{|c|}{ Total } \\
\hline & & No. & $\%$ Cured & No. & $\%$ Cured & No. & $\%$ Cured & No. & $\%$ Cured & No. & $\%$ Cured \\
\hline \multirow[t]{3}{*}{ Minor } & NAS $^{1}$ & 13 & 0.0 & 33 & 78.8 & 37 & 83.8 & 15 & 86.7 & 98 & 71.4 \\
\hline & Corynebacterium spp. & 15 & 6.7 & 36 & 58.3 & 59 & 76.3 & 9 & 100.0 & 119 & 63.9 \\
\hline & All minor & 28 & 3.6 & 69 & 68.1 & 96 & 79.2 & 24 & 91.7 & 217 & 67.3 \\
\hline \multirow[t]{10}{*}{ Major } & Staph. aureus & 26 & 0.0 & 115 & 33.0 & 98 & 41.8 & 26 & 80.8 & 265 & 37.7 \\
\hline & Strep. agalactiae & 1 & 100.0 & 1 & 100.0 & & & & & 2 & 100.0 \\
\hline & Strep. dysgalactiae & 6 & 16.7 & 15 & 93.3 & 11 & 90.9 & 1 & 100.0 & 33 & 78.8 \\
\hline & Strep. uberis & 8 & 0.0 & 36 & 61.1 & 42 & 59.5 & 11 & 54.5 & 97 & 54.6 \\
\hline & All Streptococci & 15 & 13.3 & 52 & 71.2 & 53 & 66.0 & 12 & 58.3 & 132 & 61.4 \\
\hline & E. coli & & & 2 & 100.0 & 2 & 100.0 & & & 4 & 100.0 \\
\hline & Mixed $^{2}$ & 11 & 18.2 & 33 & 33.3 & 26 & 69.2 & 9 & 88.9 & 79 & 49.4 \\
\hline & Gram -ve rods & & & 1 & 100.0 & & & & & 1 & 100.0 \\
\hline & Nocardia spp. & & & 1 & 100.0 & 4 & 100.0 & 1 & 100.0 & 6 & 100.0 \\
\hline & All majors & 52 & 7.7 & 204 & 44.1 & 183 & 54.6 & 48 & 77.1 & 480 & 46.7 \\
\hline Total glands & & 80 & 6.3 & 273 & 49.8 & 279 & 61.6 & 72 & 80.6 & 704 & 52.7 \\
\hline Total cows & & 50 & & 173 & & 175 & & 49 & & & \\
\hline
\end{tabular}

${ }^{1}$ Non-aureus staphylococcus (i.e., coagulase-negative staphylococcus), 2 , i.e. , 2 distinct bacterial species isolated.

Antimicrobial resistance was found in 128/338 (37.9\%, 95\% CI = 32.7-43.3\%) of Staph. Aureus isolates for ampicillin and penicillin. Penicillin-resistant Staph. aureus isolates were found in 13 of the 38 (34.2\%, exact $95 \% \mathrm{CI}=19.6-51.4 \%)$ herds enrolled, with the within-herd prevalence varying from 9 to $88 \%$. No isolates were resistant to cephalothin, novobiocin, or oxacillin.

\subsection{Bacteriological Cure}

The crude proportion of glands with bacteriological cure of all pathogens or major pathogens only following no treatment (Control), $3 \times 48 \mathrm{~h}, 5 \times 24 \mathrm{~h}$ and $5 \times 48 \mathrm{~h}$ interval cloxacillin treatments was 5/80 (6.3\%) and 4/52 (7.7\%), 136/273 (49.8\%) and 90/204 $(44.1 \%), 172 / 279(61.6 \%)$ and 100/183 (54.6\%), 58/72 (80.6\%) and $37 / 48(77.1 \%)$, respectively (Table 1 ).

In the final model, the bacteriological cure rate differed amongst each treatment group for all pathogens, and amongst major pathogen IMI (Figure 1a, Supplementary Tables S1 and S2). Bacteriological cure rate for all pathogens, and for major pathogen infections, was lower for cows $>3$ years of age compared with those that were 2-3 years of age (Figure 1b). Bacteriological cure rate declined with increasing quarter-level SCC prior to treatment (Figure 1c).

Amongst Staph. aureus IMI, the bacteriological cure rate was 2.4 (95\% CI =0.0-7.3), 29.8 (95\% CI = 22.0-37.7), 49.3 (95\% CI = 40.2-58.4), and 79.8 (95\% CI 65.4-94.2)\% following no treatment (control), or $3 \times 48 \mathrm{~h}, 5 \times 24 \mathrm{~h}$ and $5 \times 48 \mathrm{~h}$ interval cloxacillin treatments, respectively. The bacteriological cure rates differed between each treatment group $(p<0.05)$. Cure proportions were not affected by penicillin resistance, with 44/119 (37.0\%) versus $77 / 195$ (39.5\%) cure rate for Staph. aureus IMI that were resistant and sensitive to penicillin, respectively. Bacteriological cure declined with increasing quarter level SCC prior to treatment $(p=0.005)$ and was higher in 2- and 3-year-old compared with $>3$-year-old animals (59.1 (95\% CI 43.3-74.9) versus 36.5 (95\% CI 31.3-41.8)\% bacteriological cure rate for 2- and 3-year-olds versus $>3$-year-old cows, respectively; $p=0.02$, Supplementary Table S3). 


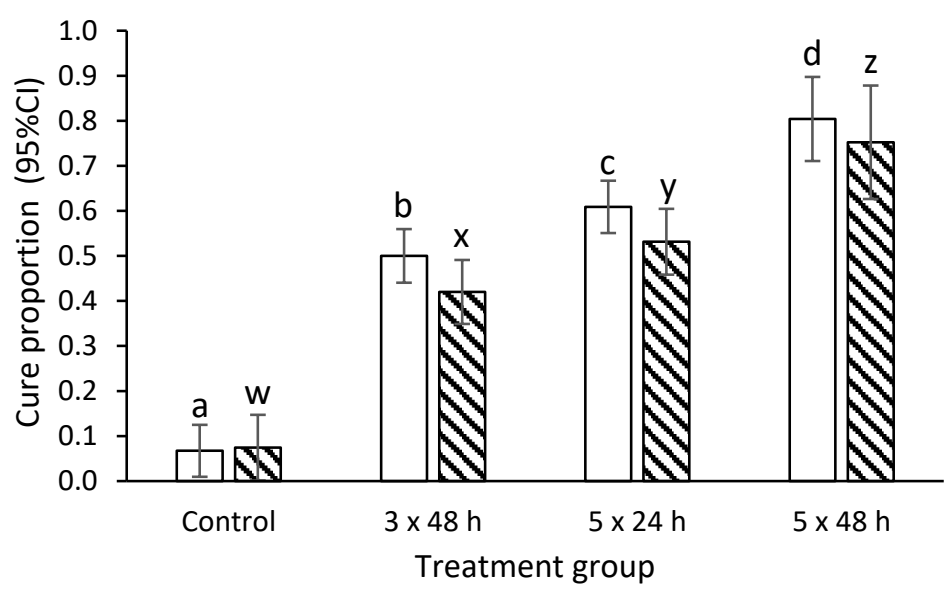

(a)

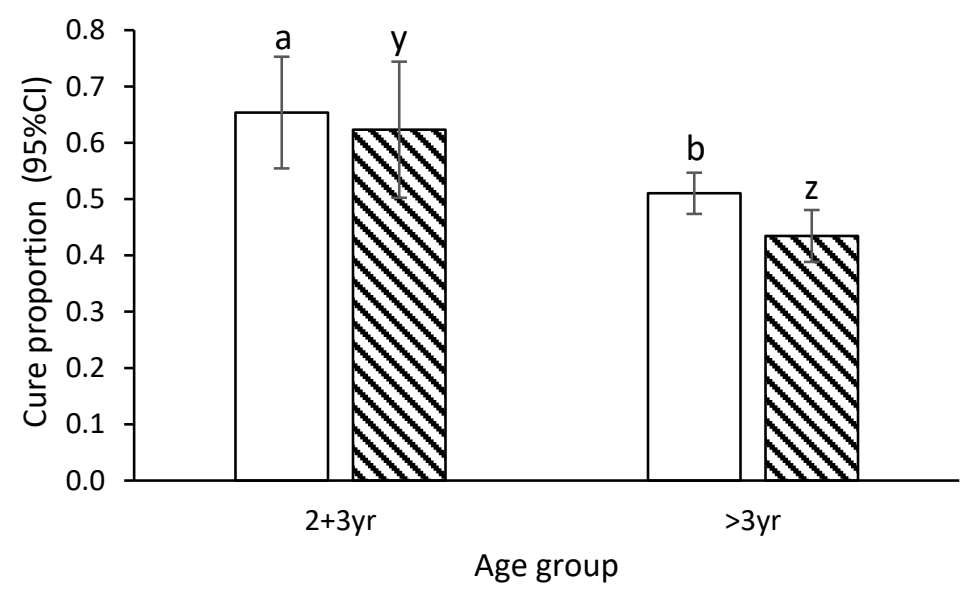

(b)

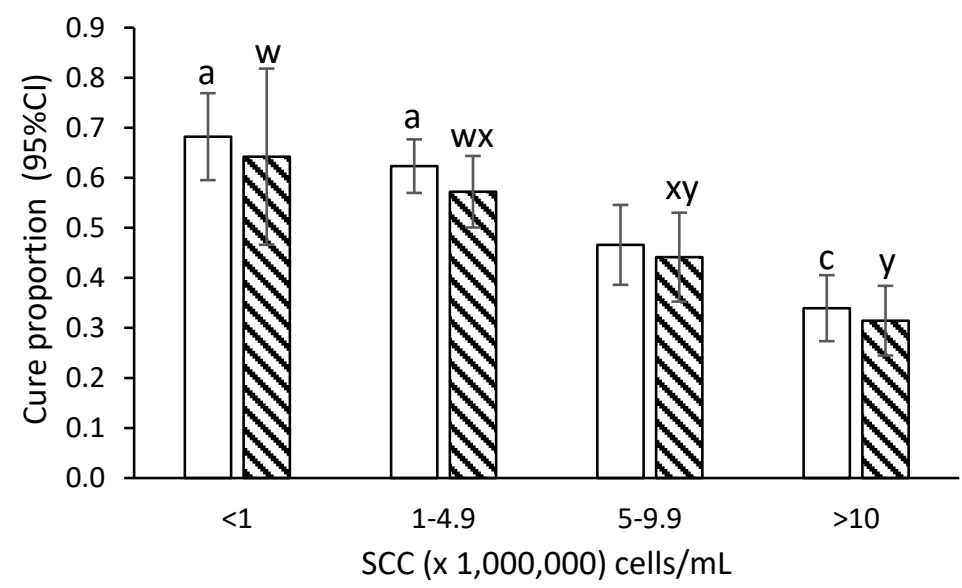

(c)

Figure 1. Estimated mean cure proportion (with $95 \%$ confidence limits) for treatment of subclinical mastitis with intramammary cloxacillin by (a) treatment group, (b) age, and (c) quarter-level SCC prior to treatment for any pathogen (open bars) or for major pathogens (cross hatched bars). Within pathogen type, columns with differing superscripts differ at $p<0.05$.

Amongst Streptococcal IMI, the bacteriological cure rates were $14.3(95 \% \mathrm{CI}=0-32.8)$, $69.8(95 \% \mathrm{CI}=56.8-82.8), 67.2(95 \% \mathrm{CI}=54.3-80.0)$, and $61.6(95 \% \mathrm{CI}=32.7-90.5) \%$ following no treatment (control), or $3 \times 48 \mathrm{~h}, 5 \times 24 \mathrm{~h}$ and $5 \times 48 \mathrm{~h}$ interval cloxacillin treatments, respectively. The bacteriological cure rates differed between the control group and each of the treatment groups (all $p<0.05$ ), but the three cloxacillin treatment groups did not differ 
from each other $(p>0.05)$. No other explanatory variables were present in the final model (Supplementary Table S4).

\subsection{New Infection Rate}

The cumulative incidences of new IMI with any pathogen or a major pathogen between enrolment and the final Day 28 sample were 150/704 glands (21.3\%) and 46/704 glands $(6.5 \%)$, respectively. The cumulative incidence for any pathogen did not differ between treatment groups $(p=0.46)$, but the cumulative incidence of new major pathogens tended to be higher $(p=0.10)$ in Control glands $(11 / 80,13.8 \%)$ than in $3 \times 48 \mathrm{~h}$ treatment glands $(14 / 273,5.1 \%)$. This is equal to overall incidence rates of 7.6 and 2.3 new IMI for any pathogen or major pathogen-only IMI per gland per 1000 days at risk.

\subsection{Quarter-Level Somatic Cell Count}

The median gland somatic cell count did not differ between groups on the day of enrolment but was lower for treatment groups $5 \times 24 \mathrm{~h}$ and $5 \times 48 \mathrm{~h}$ compared to control glands ( $p<0.01$ for each comparison) at Days 21 and 28 ( $p \leq 0.01$ for each comparison) with the $3 \times 48$ h group intermediate (Figure 2a). The median gland somatic cell count was lesser for glands that were cured of any pathogen compared to those that were not on each day of sampling ( $p<0.01$ for each comparison; Figure $2 b)$.

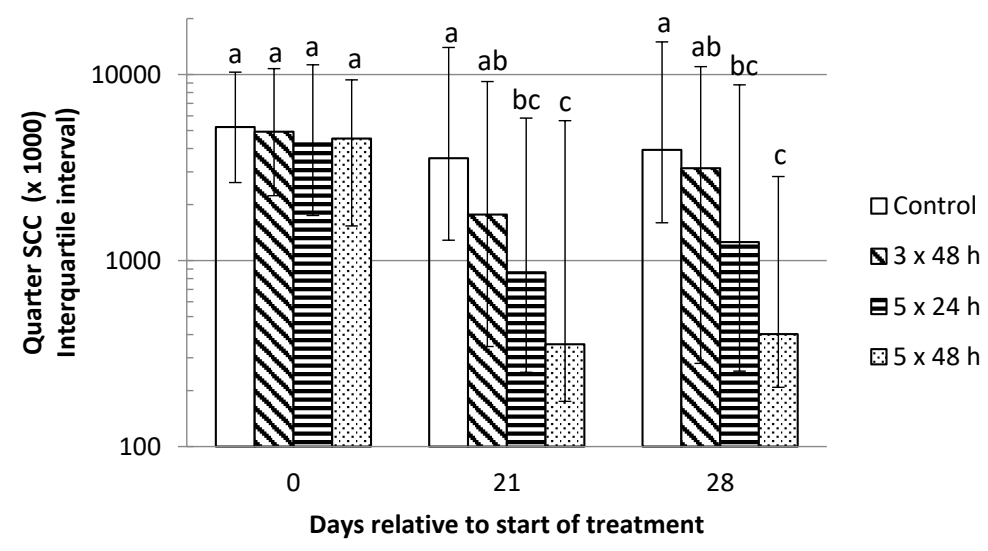

(a)

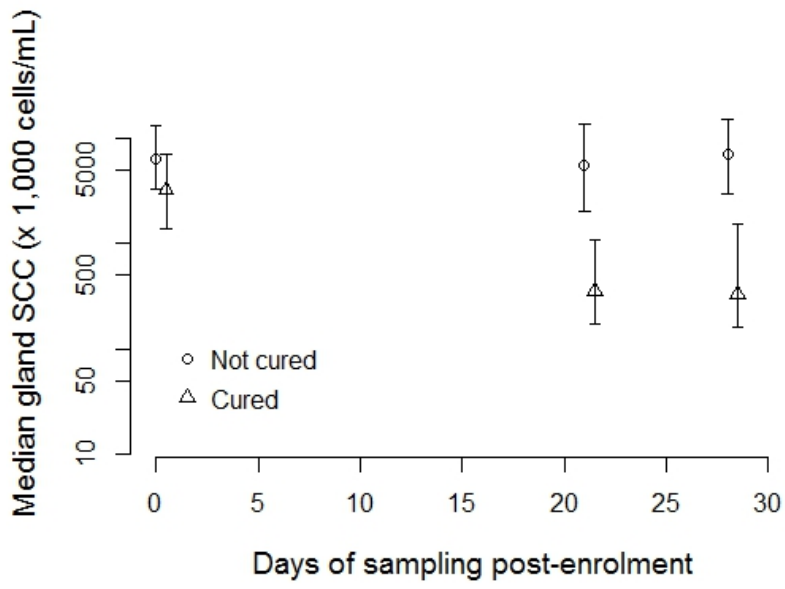

(b)

Figure 2. Median (interquartile range) of somatic cell count (SCC; $\times 1000$ cells $/ \mathrm{mL}$ ) by (a) day posttreatment and by treatment group irrespective of bacteriological cure outcome, and $(\mathbf{b})$ in glands that did or did not undergo bacteriological cure. Columns within days with superscripts differing differ at $p<0.05$. 


\subsection{Incidence of Clinical Mastitis within 28 Days of Enrolment}

The incidence of clinical mastitis within 28 days of enrolment did not differ between treatment groups $(0 / 81(0 \%), 9 / 298(3.0 \%), 9 / 292(3.1 \%)$, and $1 / 77(1.3 \%)$ for quarters with subclinical mastitis following no treatment (Control), $3 \times 48 \mathrm{~h}, 5 \times 24 \mathrm{~h}$ and $5 \times 48 \mathrm{~h}$ interval cloxacillin treatments, respectively; $p=0.36$ ).

\section{Discussion}

This negative and positive controlled, multiherd intervention study of treatment of subclinical mastitis by intramammary infusion of cloxacillin demonstrated that increasing either the frequency and/or duration of therapy resulted in increased bacteriological cure rate.

Sufficient cases were enrolled to test the hypotheses, treatment groups did not differ in terms of age, breed, teat end score, pathogen, and cows from a large number of herds were enrolled. Thus, the external validity of the study is high, and there was no bias in group allocation.

\subsection{Effect of Duration and Frequency of Treatment on Cure Rate}

The increasing cure rate observed with increasing duration and/or frequency of treatment agrees with a growing body of data showing that increasing the duration of treatment increases cure rate for the time-dependent antibiotics $[4,5,15]$. Over all pathogens, major pathogens, and Staph. aureus IMI, the $5 \times 48 \mathrm{~h}$ treatment group resulted in higher bacteriological cure than the $5 \times 24 \mathrm{~h}$ treatment group. Like other beta lactams, cloxacillin is a time-dependent antimicrobial $[13,14]$, and as the concentrations of cloxacillin in cisternal milk are likely to being above the MIC for most mastitis pathogens for up to $48 \mathrm{~h}$, the $5 \times 48 \mathrm{~h}$ treatment protocols likely resulted in concentrations above MIC for a significantly longer period than following the $5 \times 24 \mathrm{~h}$ treatment with a resultant increase in bacteriological cure rate.

Similarly, over all pathogens, major pathogens, and Staph. aureus IMI, the $5 \times 24 \mathrm{~h}$ treatment group resulted in higher bacteriological cure than the $3 \times 48 \mathrm{~h}$ treatment group. While the timing of these treatments resulted in the duration over which treatments were applied being similar (i.e., the final treatment occurred $96 \mathrm{~h}$ after the first treatment irrespective of whether three or five doses were given), it is possible that higher concentrations were achieved with the $5 \times 24 \mathrm{~h}$ dosing frequency, and associated with this, the total duration over which the cloxacillin concentration was greater than MIC may have been longer. Following infusion of a "slow release" formulation of cloxacillin, concentrations had not returned to basal level by $48 \mathrm{~h}$ post-intramammary-infusion [24]. Thus, where dosing was occurring at 24-hourly intervals, it is likely that the maximum concentrations achieved were higher than in the $3 \times 48 \mathrm{~h}$ treatment group. Additionally, due to a diffusion gradient within the mammary gland following intracisternal infusion of antimicrobials, and the limited distribution of cloxacillin within the mammary gland, it is possible that the higher concentrations potentially achieved by the higher frequency dosing (i.e., 24 versus 48 hourly) may have resulted in higher concentrations at the dorsum of the udder with potential increases in the bacteriological cure rate.

Amongst glands infected with Streptococcus (that is, Strep. agalactiae, Strep. dysgalactiae or Strep. uberis), all cloxacillin treatment groups resulted in a higher bacteriological cure than for the control group. However, as distinct from Staph. aureus, there was no difference in bacteriological cure rate between the $3 \times 48 \mathrm{~h}, 5 \times 24 \mathrm{~h}$, and $5 \times 48 \mathrm{~h}$ groups for Streptococcus spp. infections. Similarly, treatment of naturally acquired environmental streptococcal infection with zero, two, five, or eight daily doses of ceftiofur resulted in the 5- and 8-day treatments having higher bacteriological cure rates than the control group, but the cure rates amongst the three treatment groups did not differ [15]. Conversely, bacteriological cure rates of Strep. uberis infections increased following zero, two, or eight daily pirlimycin treatments [4]. Care must be taken in the interpretation of these data due to the relatively small sample size (i.e., only 41,92 , and 132 glands were infected with 
Streptococcus in $[4,15]$, and the current study, respectively). It is not clear why no increase in cure rate occurred with the longer duration treatment protocols in the current study for Streptococci. Another study [24] reported no difference in bacteriological cure rate of Streptococci following comparison of two doses $(0.2-0.6 \mathrm{~g})$, and one versus three treatments at $48 \mathrm{~h}$ intervals, or with two formulations of cloxacillin. However, this was partly due to the very high $(>90 \%)$ bacteriological cure rates observed for Strep. agalactiae and Strep. dysgalactiae irrespective of dose rate, frequency, or formulation, suggesting that even short (single)-duration treatment of $0.2 \mathrm{~g}$ of "quick release" formulation were highly effective against these Streptococci. The bacteriological cure rate for Strep. uberis overall in that same study was $82 \%$, with little variation associated with dose rate, number of doses or release formulation. The $\mathrm{MIC}_{90}$ of Strep. dysgalactiae and Strep. uberis isolated from cows diagnosed with mastitis in New Zealand were 0.25 and $4.0 \mu \mathrm{g} / \mathrm{mL}$, respectively, [21]. Similarly, MICs for Strep. uberis for cloxacillin of $4 \mu \mathrm{g} / \mathrm{mL}$ were reported from France [28] and an MIC of $2 \mu \mathrm{g} / \mathrm{mL}$ for oxacillin (the preferred class antimicrobial) from Germany [29]. Mutations in penicillin binding protein $2 \times$ are associated with an elevated cloxacillin MIC and poorer bacteriological cure rates amongst Strep. uberis isolates [30,31]. Concentrations of cloxacillin in milk following infusion of $200 \mathrm{mg}$ of a "slow release" formulation on three occasions at $48 \mathrm{~h}$ intervals peaked at approximately $30 \mu \mathrm{g} / \mathrm{mL}$, and remained above $4 \mu \mathrm{g} / \mathrm{mL}$ for 7 days [24], suggesting that concentrations of cloxacillin achieved following intramammary infusion were likely above the Strep. uberis MIC for an extended period. As neither the MIC of the Strep. uberis isolates nor the concentrations cloxacillin in milk were determined in the current study, it is not clear whether some Strep. uberis isolates have MICs such that cloxacillin concentrations achieved are not optimal.

\subsection{Effect of Age and SCC Duration on Cure Rate}

The cure rate declined with age of the cow and with increasing SCC prior to treatment. Declining cure rates have been associated with increasing cow age following treatment of both subclinical $[4,32]$ and clinical mastitis [7,33]. However, another study of clinical mastitis treatment did not find an association between age and cure rate [34]. Age may be a proxy for chronicity of infection, which may affect bacteriological cure rate. In the current study, effects of age were present in the models considering all intramammary infections and major pathogen infections, but not in the model of Streptococci. This may reflect differences in the epidemiology of Streptococci and Staph. aureus, as Streptococci behave predominantly as environmental pathogens, meaning prevalence of streptococcal infection may not vary with age, but in contrast, Staph. aureus, due to its contagious nature, may be more prevalent and of greater duration in older animals, with increasing chronicity associated with lower cure rates.

The cure rate declined with increasing gland-level SCC before treatment in the current study, as has been demonstrated in previous studies [32,34]. The higher SCC may be associated with more severe infections, potentially related to the virulence of the pathogen.

Stage of lactation (days in milk) was not associated with cure in the current study. This contrasts with several other studies that have demonstrated effects of stage of lactation on cure. There was a stage of lactation by treatment interaction in a study assessing zero, two and eight daily treatments with pirlimycin, whereby cure rate declined with stage of lactation in untreated controls, whereas there was an increased cure rate with increasing stage of lactation amongst animals treated for 2 days with pirlimycin, but this effects occurred only in the first 100 days of lactation (relative to $>200$ days) amongst those cows treated for 8 days [4]. Similarly, bacteriological cure rate was lower in the first 100 days of lactation compared to in cows $>200$ days of lactation amongst subclinical Staph. aureus cases [32]. In the current study, most cows (80\%) were $<100$ days in milk and the median days in milk was 69 days. Thus, there is limited power in the current study to demonstrate any effect of stage of lactation, if present. 


\subsection{Effect of Penicillin Resistance amongst Staph. aureus Isolates on Cure Rate}

Penicillin resistance was present in $38 \%$ of the Staph. aureus isolates tested in the current study. Previous New Zealand studies have reported penicillin resistance of bovine mastitis Staph. aureus isolates to be in the range of $25 \%$ and $38 \%$ [21,35,36]. Presence of penicillin resistance did not affect cure rate of Staph. aureus in the current study. The sample size was relatively small for testing this hypothesis with post hoc analysis, finding that with 120 cases/group, a difference of $22 \%$ versus $37 \%$ in bacteriological cure rate could have been detected. However, as the antibiotic used in the current study (cloxacillin) is stable against beta-lactamases (a common mechanism of resistance in Staph. aureus), this result is not unexpected. Conversely, where glands infected with Staph. aureus were treated with a narrow-spectrum penicillin which was susceptible to beta-lactamases, the bacteriological cure rates in resistant isolates were significantly lower than those that were sensitive [5]. However, other studies have shown that penicillin resistance has been associated with poorer bacteriological cure rates $[7,32,37]$, irrespective of the antimicrobial used. In those studies, as in the current one, the antibiotics used were stable to beta-lactamases, and hence the effect of decreased cure rate in the beta lactamase producing isolates was independent of the antimicrobial used. It has been hypothesized that bacteria that have the beta-lactamase genes may also carry other virulence factors and hence it is these other factors, rather than the presence of the beta lactamase per se, that accounts for the lower cure rates [38].

\subsection{Effect of Treatment on Gland-Level SCC}

The SCC at gland level were lower in glands treated with cloxacillin at $5 \times 48$ and $5 \times 24 \mathrm{~h}$ intervals, than the control glands. Bacteriological cure resulted in lower glandlevel SCC. This agrees with previous studies demonstrating that extension of duration of therapy is associated with increased pathological cure rate, and hence lower SCC [3,4]. It should be noted that $<20 \%$ of glands had SCC of $<200,000$ cells $/ \mathrm{mL}$ by Day 28 posttreatment. In practical terms, cows treated for subclinical mastitis may still have elevated SCC at the time of return to milk supply, and where several cows in a herd have been treated, this may increase the bulk milk SCC.

\section{Materials and Methods}

This prospective, randomized, positive- and negative-controlled study was undertaken using cows from 44 spring-calving, predominantly pasture-fed dairy cows from the Waikato region of New Zealand. Cows were milked twice a day. The herds were a convenience sample from amongst herds serviced by one veterinary business (Anexa) that was willing to follow the study protocol, to undertake at least 3 production recordings per lactation, and that was allowed access to electronic and hard-copy cow records and signed an informed consent form.

\subsection{Cow Procedures}

Cows were selected based on having a cow-composite somatic cell count (SCC) of $>500,000$ cells $/ \mathrm{mL}$ at a production (herd-test) recording within the preceding 14 days. Cows were excluded if they had been treated with antimicrobials in the preceding 30 days. Remaining cows were separated from the herd between milkings and examined by experienced technicians. Cows with one or more teat ends with very severe hyperkeratosis [39] or which had one or more nonfunctional or "light" quarters, that is, glands visually estimated to have $<80 \%$ of the volume of other glands within the cow, or did not have at least one gland positive (i.e., greater than trace) on the Californian Mastitis test (CMT) were excluded. A cow could only be enrolled once in the study, and cow enrolment occurred between September 2010 and December 2011.

Glands that were CMT-positive from amongst the cows meeting these enrolment criteria had duplicate foremilk milk samples collected for subsequent microbiology and quarter-level SCC determination. Samples for microbiology were held at $-20{ }^{\circ} \mathrm{C}$ before 
processing, samples for SCC determination were preserved with one drop of bronopol, and the samples were held at $4{ }^{\circ} \mathrm{C}$ for up to 7 days before submission to the laboratory.

Cows with at least one gland meeting the inclusion criteria were randomly assigned to the negative control group (i.e., no treatment), 3 intramammary infusions at $24 \mathrm{~h}$ intervals $(3 \times 24 \mathrm{~h}), 5$ treatments at $24 \mathrm{~h}$ interval $(5 \times 24 \mathrm{~h})$, and 5 treatments at $48 \mathrm{~h}$ intervals $(5 \times 48 \mathrm{~h})$ in a 1:4:4:1 pattern within blocks of 10 cows within each herd. Where more than one gland within cow met the inclusion criteria, all glands within the cow were treated the same way. The treatment was one of two commercial batches of a $200 \mathrm{mg}$ cloxacillin sodium formulation (Orbenin LA, Zoetis Animal Health, Auckland, New Zealand Animal Compounds Veterinary Medicine registration number A3664). Following aseptic teat-end preparation by scrubbing with a cotton wool ball soaked in $70 \%$ methylated spirits, treatment was administered using the "partial insertion" method, that is, the tip of the treatment cannula was inserted approximately $3 \mathrm{~mm}$ into the teat canal, the end of the teat canal was included with a thumb and forefinger and the antimicrobial gently infused. The antimicrobial was manually dispersed within the mammary gland by massage. Following infusion, teat antiseptic ( $0.25 \%$ available iodine) was applied. The milk withholding period was 7 or 8 milkings following the $3 \times 48 \mathrm{~h}$ treatment, and the $5 \times 24 \mathrm{~h}$ and $5 \times 48 \mathrm{~h}$, respectively.

All enrolled glands were re-examined by trained technicians $21( \pm 3)$ and $28( \pm 3)$ days after the first treatment. A single milk sample $(\sim 5 \mathrm{~mL})$ was collected for bacteriology and a further sample $(\sim 25 \mathrm{~mL})$ collected for gland-level SCC determination. Additionally, the presence or absence of changes to the milk (i.e., flecks or clots or wateriness of the milk) and/or heat/swelling of the mammary gland were recorded at these time points (Figure 3).

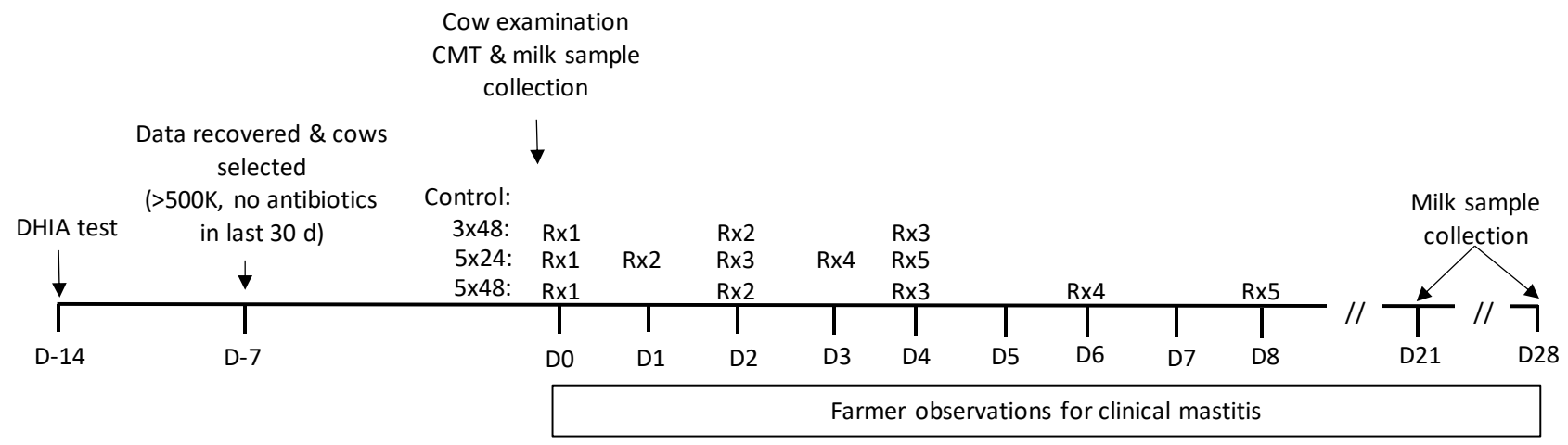

Figure 3. Diagram of cow procedures including data collation from dairy herd improvement testing (DHIA test), cow examination, California mastitis test (CMT) and treatment regime. Cows were allocated to no treatment (Control), 3 intramammary infusions of $200 \mathrm{mg}$ cloxacillin at a $48 \mathrm{~h}$ interval $(3 \times 48), 5$ treatments at $24 \mathrm{~h}$ interval $(5 \times 24)$, or 5 treatments at 48 hourly intervals $(5 \times 48)$. Rx indicates intramammary treatment.

Herd owners and staff were asked to monitor for presence of clinical mastitis (i.e., presence of changes to the milk such as presence of flecks or clots) and/or changes to the mammary gland (heat/swelling) from the time of initiation of treatment through to Day 28. Where clinical mastitis was detected, the herd owner treated such quarters with antimicrobials and recorded the cow, gland position, and treatment, and these data were later recovered for analysis.

A total of 1171 cows were considered eligible for the study based on SCC data, of which 518 were excluded, 276 related to recent antimicrobial usage, 93 due to presence of light or nonfunctional glands, 69 because none of the glands were CMT positive, 47 due to presence of very rough teat-end hyperkeratosis and 33 as they were systemically ill or had only recently calved. Hence, 653 cows were randomly allocated to the treatment groups. A further 14, 90, 87, and 15 cows in the Control, $3 \times 48 \mathrm{~h}, 5 \times 24 \mathrm{~h}$, and $5 \times 48 \mathrm{~h}$ 
groups, respectively, were excluded due to no bacterial growth of the selected quarter, or the samples being defined as contaminated or culturing a yeast in the laboratory.

Data from 704 glands from 447 cows from 37 herds were considered for analysis. The distribution of cows among the treatment groups was $50(11 \%)$ in the control group, $173(39 \%)$ in the $3 \times 48 \mathrm{~h}$ group, $175(39 \%)$ in the $5 \times 24 \mathrm{~h}$ group and $49(11 \%)$ in the $5 \times 48 \mathrm{~h}$ group (Supplementary Table S5). The distribution of cow age and breed categories did not differ between treatment groups ( $p=0.55$ and 0.63 , respectively). The median days in milk at enrolment was not different between treatment groups $(p=0.84)$, but the median SCC (at cow level) at the most recent herd test prior to enrolment differed between treatment groups ( $p=0.006$; Supplementary Table S6).

At gland level, $80(11 \%)$ glands were in the control group, $273(39 \%)$ in the $3 \times 48 \mathrm{~h}$ group, $279(40 \%)$ in the $5 \times 24 \mathrm{~h}$ group and $72(10 \%)$ in the $5 \times 48 \mathrm{~h}$ group. The distribution of gland position $(p=0.95)$, teat-end score $(p=0.59)$, and CMT score $(p=0.58)$ at enrolment did not differ among the treatment groups (Supplementary Table S7). The median SCC at individual gland level did not differ between treatment groups $(5501(345-27,109)$, $4730(43-30,570), 4209$ (49-29,758), and 4393 (219-22,299) median (minimum-maximum) SCC $(\times 1000$ cells $/ \mathrm{mL})$ for quarters assigned to be in the Control group, $3 \times 48 \mathrm{~h}, 5 \times 24 \mathrm{~h}$ and $5 \times 48$ h, respectively $p=0.57$ ).

This study was blinded by not including the treatment group on lists of animals in glands to be sought to be sampled following the initial treatment, and all samples were identified with unique sample identification that did not include treatment group.

\subsection{Laboratory Techniques}

\subsubsection{Microbiology}

Microbiology was undertaken following the procedures recommended by the National Mastitis Council, USA [40]. Briefly, $10 \mu \mathrm{L}$ of milk was streaked onto a quarter of a $5 \%$ blood agar plate containing $0.1 \%$ esculin (Fort Richard, Auckland, New Zealand), and incubated at $37^{\circ} \mathrm{C}$ for $48 \mathrm{~h}$. The genus of bacteria was determined based on colony morphology, Gram stain, esculin reaction, coagulase, and CAMP tests. Coliforms were sub-cultured on MacConkeys agar, and an oxidase test performed.

Non-aureus staphylococci (NAS) and Corynebacterium spp. were defined as 'minor' pathogens while Staph. aureus, Streptococcus agalactiae, Streptococcus dysgalactiae, Strep. uberis, Nocardia spp. and Escherichia coli were defined as 'major' pathogens.

Staphylococcus aureus isolated from the pretreatment samples were kept on Dorset egg slopes (Fort Richard, Auckland, New Zealand) at $4{ }^{\circ} \mathrm{C}$ and antimicrobial sensitivity determined by zone diffusion testing using discs for ampicillin, cephalothin, novobiocin, oxacillin and penicillin following CLSI methodology [41].

\subsubsection{Somatic Cell-Count Determination}

Somatic cell counting for individual gland samples and from composite milk samples from herd testing was performed using flouro-optic methods (Fossomatic 5000, Foss, Denmark) by the LIC Testlink Laboratory, Riverlea Rd, Hamilton, New Zealand.

\subsection{Data Handling and Analysis}

Data were stored in a custom-built relational database (Microsoft Access 2007, Redmond, WA, USA). Statistical analysis was performed using R [42] or STATA v17 (Stata Corp., College Station, TX, USA). Statistical significance was declared at $p<0.05$.

The primary outcome variable was bacteriological cure of glands. This was defined as the presence of the bacterial species present prior to treatment (i.e., Day 0) at neither Day 21 nor 28 post-treatment. Where one or more microbiology results were defined as contaminated (i.e., $>2$ morphologically distinct bacterial colonies present) the bacteriological cure status of the gland could not be determined and was coded as "null". A new intramammary infection was defined as occurring where a bacterial species was isolated at 
either Day 21 or 28 that was not present at Day 0. Note that a gland could be defined both as a cured and as having a new intramammary infection.

Tables were made of descriptive statistics of the cows and glands in the final data set. Differences were examined by chi-squared test between cows in different treatment groups for categories of age (coded as 2-3 vs. $>3$ years of age), breed (coded as pure breed if $\geq 12$ /16th of that breed, otherwise crossbred), number of days in milk at enrolment and cow-level SCC prior to enrolment; and differences between glands enrolled in treatment groups for gland position (coded as fore vs. rear glands), teat-end hyperkeratosis score (i.e., none, smooth, or rough), and gland SCC (coded as <1 million, 1-4.9 million, 5-9.9 million, and $>10$ million cells $/ \mathrm{mL}$ ) at enrolment. Pairwise comparisons were adjusted for multiple comparisons using the Bonferroni correction. Somatic cell count was categorized for analysis, or analysis was performed by nonparametric tests because log-transformation did not adequately normalize the distribution.

Initially, univariate associations were tested by chi-squared test between the outcome variables (IMI cure proportion for all pathogens, IMI cure proportion for major pathogens, IMI cure proportion for Staph. aureus, and IMI cure proportion for Streptococci (i.e., Strep agalactiae, Strep. dysgalactiae, and Strep. uberis combined)) and possible predictor variables (treatment group, categories of age, breed, days in milk at enrolment, enrolment teat-end score, gland position, enrolment gland SCC and presence of penicillin resistance (for Staph. aureus isolates only)). Because the outcome variables could not be considered independent of each other and were measured at the gland-level, which were clustered within cows, accounting for this multilevel data structure was necessary in the final model to estimate treatment effects. Hence, generalized linear mixed models [43] for the outcome variables were built by manual forward stepwise addition of variables significant $(p<0.2)$ from the univariate analysis and known potential confounding variables, e.g., age category and days in milk at start of treatment. Treatment group was forced into the models as a fixed effect. Variables were retained in the final model where they were significant $(p<0.05)$ or were effect modifiers of the association between treatment and cure proportion (changed regression coefficient $>15 \%$ ). The probability of cure was predicted from the final models with adjustment for the effect of other retained variables and these results were then tabulated.

\subsection{Power Analyses}

Based on expected bacteriological cure rates in the negative control group of $20 \%$ and in the $5 \times 48$ treatment group of $80 \%$, respectively [5], a priori 100,400,400, and 100 glands eligible for treatment within each of the control, $3 \times 48 \mathrm{~h}, 5 \times 24 \mathrm{~h}$, and $5 \times 48 \mathrm{~h}$ treatment groups were thought to be required, respectively.

Supplementary Materials: Supplementary tables are available at Figshare.com (DOI 10.6084/m9.figshare.19127900).

Author Contributions: Conceptualization, S.M. and C.W.R.C.; methodology, S.M., L.M.C., H.M.H. and C.W.R.C.; software, C.W.R.C.; validation, S.M. and C.W.R.C.; formal analysis, C.W.R.C.; investigation, S.M.; resources, S.M.; data curation, L.M.C., H.M.H. and C.W.R.C.; writing-S.M. and C.W.R.C.; writing-review and editing, S.M. and C.W.R.C.; visualization C.W.R.C.; supervision, C.W.R.C.; project administration, S.M.; funding acquisition, S.M. All authors have read and agreed to the published version of the manuscript.

Funding: Product was supplied by, and the research was funded by, Pfizer (now Zoetis) Animal Health, Parkville, Victoria, Australia.

Institutional Review Board Statement: Prior approval to conduct this study was granted by the Ruakura Animal Ethics Committee (Decision Number 12176) of AgResearch, Hamilton, New Zealand.

Data Availability Statement: Data is available upon request.

Acknowledgments: The technical assistance of Elizabeth Blythe, Kegan Burrell, Ricardo Ferreria, Alan Findlay, Krista Glover, Ondine Habgood, Amanda Hallett, Kristin Harvey, Hanna Jenson, 
Stuart Moody, Sally Paris, Gaylene Perkinson, Sue Pothecary, Joanne Newell, and Cathy Yanez in undertaking clinical assessment and sampling and treatment of cows are gratefully acknowledged. The cooperation of the herdowners and their staff is gratefully acknowledged.

Conflicts of Interest: The authors declare no conflict of interest. The funders had no role in the design of the study; in the collection, analyses, or interpretation of data; in the writing of the manuscript, or in the decision to publish the results.

\section{References}

1. Ruegg, P.L. Making antibiotic treatment decisions for clinical mastitis. Vet. Clin. Food Anim. Pract. 2018, 34, 413-425. [CrossRef] [PubMed]

2. Halasa, T.; Huijps, K.; Osterás, O.; Hogeveen, H. Economic effects of bovine mastitis and mastitis management: A review. Vet. Q 2007, 29, 18-31. [CrossRef] [PubMed]

3. St.Rose, S.G.; Swinkels, J.M.; Kremer, W.D.J.; Kruitwagen, C.L.J.J.; Zadoks, R.N. Effect of penethamate hydriodide treatment on bacteriological cure, somatic cell count and milk production of cows and quarters with chronic subclinical Streptococcus uberis or Streptococcus dysgalactiae infection. J. Dairy Res. 2003, 70, 387-394. [CrossRef]

4. Deluyker, H.A.; Van Oye, S.N.; Boucher, J.F. Factors affecting cure and somatic cell count after pirlimycin treatment of subclinical mastitis in lactating cows. J. Dairy Sci. 2005, 88, 604-614. [CrossRef]

5. Steele, N.; McDougall, S. Effect of prolonged duration therapy of subclinical mastitis in lactating dairy cows using penethamate hydriodide. N. Z. Vet. J. 2014, 62, 38-46. [CrossRef]

6. Barlow, J.W.; Zadoks, R.N.; Schukken, Y.H. Effect of lactation therapy on Staphylococcus aureus transmission dynamics in two commercial dairy herds. BMC Vet. Res. 2013, 9, 28. [CrossRef]

7. Sol, S.; Sampimon, O.C.; Barkema, H.W.; Schukken, Y.H. Factors associated with cure after therapy of clinical mastitis caused by Staphylococcus aureus. J. Dairy Sci. 2000, 83, 278-284. [CrossRef]

8. Sandholm, M.; Kaartinen, L.; Pyorala, S. Bovine mastitis-why does therapy not always work? An overview. J. Vet. Pharmacol. Therap. 1990, 13, 248-260. [CrossRef]

9. Hillerton, J.E.; Semmens, J.E. Comparsion of treatment of mastitis by oxytocin or antibiotics following detection according to changes in milk electrical conductivity prior to visible signs. J. Dairy Sci. 1999, 82, 93-98. [CrossRef]

10. Davis, W.T.; Maplesden, D.C.; Natzke, R.P.; Philpot, W.N.; Garrett, P.; Card, C.S. Benzathine cloxacillin intramammary infusion for treatment of mastitis in dry cows. Vet. Med. Small Anim. Clin. 1975, 70, 287-289.

11. Ziv, G.; Storper, M. Intramuscular treatment of subclinical staphylococcal mastitis in lactating cows with penicillin G, methicillin and their esters. J. Vet. Pharmacol. Therap. 1985, 8, 276-283. [CrossRef] [PubMed]

12. Owens, W.E.; Ray, C.H.; Watts, J.L.; Yancey, R.J. Comparison of success of antibiotic therapy during lactation and results of antimicrobial susceptibility tests for bovine mastitis. J. Dairy Sci. 1997, 80, 313-317. [CrossRef]

13. Craig, W.A. Choosing an Antibiotic on the basis of Pharmacodynamics. Ear, Nose, Throat J. 1998, 77, 7.

14. McKellar, Q.A.; Sanchez Bruni, S.F.; Jones, D.G. Pharmacokinetic/pharmacodynamic relationships of antimicrobial drugs used in veterinary medicine. J. Vet. Pharmacol. Therap. 2004, 27, 503-514. [CrossRef] [PubMed]

15. Oliver, S.P.; Gillespie, B.E.; Headrick, S.J.; Moorehead, H.; Lunn, P.; Dowlen, H.H.; Johnson, D.L.; Lamar, K.C.; Chester, S.T.; Moseley, W.M. Efficacy of extended ceftiofur intramammary therapy for treatment of subclinical mastitis in lactating dairy cows. J. Dairy Sci. 2004, 87, 2393-2400. [CrossRef]

16. Gillespie, B.E.; Moorehead, H.; Lun, P.; Dowlen, H.; Johnson, D.L.; Lamar, K.C.; Lewis, M.J.; Ivey, S.J.; Halberg, J.; Chester, S.; et al. Efficacy of extended pirlimycin therapy for treatment of environmental Streptococcus spp and Staphylococcus aureus intramammary infections in lactating dairy cows. Vet. Therap. 2002, 3, 373-380.

17. McDougall, S.; Clausen, L.; Hintukainen, J.; Hunnam, J. Randomized, controlled, superiority study of extended duration of therapy with an intramammary antibiotic for treatment of clinical mastitis. J. Dairy Sci. 2019, 102, 4376-4386. [CrossRef]

18. Tomazi, T.; Sumnicht, M.; Tomazi, A.C.C.H.; Silva, J.C.C.; Bringhenti, L.; Duarte, L.M.; Silva, M.M.M.; Rodrigues, M.X.; Bicalho, R.C. Negatively controlled, randomized clinical trial comparing different antimicrobial interventions for treatment of clinical mastitis caused by gram-positive pathogens. J. Dairy Sci. 2021, 104, 3364-3385. [CrossRef]

19. Hendriksen, R.S.; Mevius, D.J.; Schroeter, A.; Teale, C.; Meunier, D.; Butaye, P.; Franco, A.; Utinane, A.; Amado, A.; Moreno, M.; et al. Prevalence of antimicrobial resistance among bacterial pathogens isolated from cattle in different European countries: 2002-2004. Acta Vet. Scand. 2008, 50, 28. [CrossRef]

20. Kalmus, P.; Aasmäe, B.; Kärssin, A.; Orro, T.; Kask, K. Udder pathogens and their resistance to antimicrobial agents in dairy cows in Estonia. Acta Vet. Scand. 2011, 53, 4. [CrossRef]

21. McDougall, S.; Hussein, H.; Petrovski, K. Antimicrobial resistance in Staphylococcus aureus, Streptococcus uberis and Streptococcus dysgalactiae from dairy cows with mastitis. N. Z. Vet. J. 2014, 62, 68-76. [CrossRef] [PubMed]

22. Bagcigil, A.F.; Taponen, S.; Koort, J.; Bengtsson, B.; Myllyniemi, A.-L.; Pyörälä, S. Genetic basis of penicillin resistance of S. aureus isolated in bovine mastitis. Acta Vet. Scand. 2012, 54, 69. [CrossRef] 
23. Nayler, J.H.C.; Long, A.A.W.; Brown, D.M.; Acred, P.; Rolinson, G.N.; Batchelor, F.R.; Stevens, S.; Sutherland, R. Chemistry, toxicology, pharmacology and microbiology of a new acid-stable penicillin, resistant to penicillinase (BRL 1621,). Nature 1962, 195, 1264-1267. [CrossRef]

24. Wilson, C.D.; Westgarth, D.R.; Kingwill, R.G.; Griffin, T.K.; Neave, F.K.; Dodd, F.H. The effect of infusion of sodium cloxacillin in all infected quarters of lactating cows in sixteen herds. Br Vet J. 1972, 128, 71-86. [CrossRef]

25. Davis, W.T.; Maplesdon, D.C.; Natzke, R.P.; Philpot, W.N. Sodium cloxacillin for treatment of mastitis in lactating cows. J. Dairy Sci. 1975, 58, 1822-1827. [CrossRef]

26. Browning, J.W.; Mein, G.A.; Barton, M.; Nicholls, T.J.; Brightling, P. Effects of antibiotic therapy at drying off on mastitis in the dry period and early lactation. Aust. Vet. J. 1990, 67, 440-442. [CrossRef]

27. Halasa, T.; Nielen, M.; Whist, A.C.; Østerås, O. Meta-analysis of dry cow management for dairy cattle. Part 2. Cure of existing intramammary infections. J. Dairy Sci. 2009, 92, 3150-3157. [CrossRef]

28. Guerin-Faublee, V.; Carret, G.; Houffschmitt, P. In vitro activity of 10 antimicrobial agents against bacteria isolated from cows with clinical mastitis. Vet. Rec. 2003, 152, 466-471. [CrossRef]

29. Tenhagen, B.; Köster, G.; Wallman, J.; Heuwieser, W. Prevalence of mastitis pathogens and their resistance against antimicrobial agents in dairy cows in Brandenburg, Germany. J. Dairy Sci. 2006, 89, 2542-2551. [CrossRef]

30. Haenni, M.; Galofaro, L.; Ythier, M.; Giddey, M.; Majcherczyk, P.; Moreillon, P.; Madec, J.-Y. Penicillin-binding protein gene alterations in Streptococcus uberis isolates presenting decreased susceptibility to penicillin? Antimicrob. Agents Chemother. 2010, 54, 1140-1145. [CrossRef]

31. McDougall, S.; Clausen, L.; Ha, H.-J.; Gibson, I.; Bryan, M.; Hadjirin, N.; Lay, E.; Raisen, C.; Ba, X.; Restif, O.; et al. Mechanisms of beta-lactam resistance of Streptococcus uberis isolated from bovine mastitis cases. Vet. Micro. 2020, 242, 108592. [CrossRef] [PubMed]

32. Sol, J.; Sampimon, O.C.; Snoep, J.J.; Schukken, Y.H. Factors associated with bacteriological cure during lactation after therapy for subclinical mastitis caused by Staphylococcus aureus. J. Dairy Sci. 1997, 80, 2803-2808. [CrossRef]

33. McDougall, S.; Arthur, D.G.; Bryan, M.A.; Vermunt, J.J.; Weir, A.M. Clinical and bacteriological response to treatment of clinical mastitis with one of three intramammary antibiotics. N. Z. Vet. J. 2007, 55, 161-170. [CrossRef] [PubMed]

34. Bradley, A.J.; Green, M.J. Factors affecting cure when treating bovine clinical mastitis with cephalosporin-based intramammary preparations. J. Dairy Sci. 2009, 92, 1941-1953. [CrossRef] [PubMed]

35. Grinberg, A.; Lopez-Villalobos, N.; Lawrence, K.; Nulsen, M. Prediction of penicillin resistance in Staphylococcus aureus isolates from dairy cows with mastitis, based on prior test results. N. Z. Vet. J. 2005, 53, 332-335. [CrossRef]

36. Petrovski, K.R.; Grinberg, A.; Williamson, N.B.; Abdalla, M.E.; Lopez-Villalobos, N.; Parkinson, T.J.; Tucker, I.G.; Rapnicki, P. Susceptibility to antimicrobials of mastitis-causing Staphylococcus aureus, Streptococcus uberis and Str. dysgalactiae from New Zealand and the USA as assessed by the disk diffusion test. Aust. Vet. J. 2015, 93, 227-233. [CrossRef] [PubMed]

37. Taponen, S.; Jantunen, A.; Pyorala, E.; Pyorala, S. Efficacy of targeted 5-day combined parenteral and intramammary treatment of clinical mastitis caused by penicillin-susceptible or penicillin-resistant Staphylococcus aureus. Acta Vet. Scand. 2003, 44, 53-62. [CrossRef] [PubMed]

38. Barkema, H.W.; Schukken, Y.H.; Zadoks, R.N. The role of cow, pathogen, and treatment regimen in the therapeutic success of bovine Staphylococcus aureus mastitis. J. Dairy Sci. 2006, 89, 1877-1895. [CrossRef]

39. Mein, G.A.; Neijenhuis, F.; Morgan, W.F.; Reinemann, D.J.; Hillerton, J.E.; Baines, J.R.; Ohnstad, I.; Rasmussen, M.D.; Timms, L.; Britt, J.S.; et al. Evaluation of bovine teat conditions in commercial dairy herds 1. Non-infectious factors. In Proceedings of the 2nd International Symposium on Mastitis and Milk Quality, Vancouver, BC, Canada, 12-14 September 2001; NMC Inc.: Madison, WI, USA, 2001; pp. 347-351.

40. Hogan, J.S.; Gonzalez, R.N.; Harmon, R.J.; Nickerson, S.C.; Oliver, S.P.; Pankey, J.W.; Smith, K.L. (Eds.) Laboratory Handbook on Bovine Mastitis; NMC Inc.: Madison, WI, USA, 1999.

41. CLSI (Ed.) Performance Standards for Antimicrobial Disk and Dilution Susceptibility Tests for Bacteria Isolated from Animals; Approved Standard, 4th ed.; CLSI: Wayne, PA, USA, 2013.

42. R Development Core Team. R: A Language and Environment for Statistical Computing, 2.14.1; R Foundation for Statistical Computing: Vienna, Austria, 2012.

43. Bailey, D.; Alimadhi, F. Logit.mixed: Mixed Effects Logistic Model. In Zelig: Everyone's Statistical Software; Imai, K., King, G., Lau, O., Eds.; R Foundation for Statistical Computing: Vienna, Austria, 2007; Available online: http://gking.harvard.edu/ (accessed on 29 April 2012). 